\title{
PERBEDAAN PENINGKATAN HASIL BELAJAR BIOLOGI SISWA ANTARA MODEL PROBLEM BASED LEARNING DENGAN MODEL INQUIRY LEARNING
}

\author{
Yunita Wardianti ${ }^{1}$, Linna Fitriani ${ }^{2}$, Wayan Ema Astuti ${ }^{3}$ \\ STKIP PGRI Lubuklinggau ${ }^{1,2,3}$ \\ yunita.wardianti13@gmail.com ${ }^{1}$
}

\begin{abstract}
ABSTRAK
Penelitian ini bertujuan untuk mengetahui peningkatan hasil belajar biologi siswa dengan menggunakan model Problem Based Learning (PBL)dan model Inquiry Learning di Kelas X SMA Negeri 2 Lubuklinggau. Penelitian ini merupakan jenis penelitian deskriptif kuantitatif dengan menggunakan metode kuasi eksperimen. Populasi dalam penelitian ini adalah seluruh siswa Kelas X SMA Negeri 2 Lubuklinggau yang berjumlah 391 siswa, sedangkan sampel penelitian yaitu kelas X.7 berjumlah 39 siswa sebagai kelas eksperimen I dan kelas X.10 berjumlah 40 siswa sebagai kelas eksperimen II yang diperoleh dengan menggunakan teknik cluster sampling. Data penelitian diperoleh dengan teknik tes bentuk soal essay. Teknik analisis data dengan uji t. Hasil penelitian, berdasarkan hasil analisis dengan uji t terhadap nilai akhir dapat disimpulkan bahwa Ho ditolak dan Ha diterima karena nilai Sig. (2-tailed) sebesar 0,513 lebih besar dari $\alpha=0,05$. Simpulan, peningkatan hasil belajar biologi siswa dengan model pembelajaran Problem Based Learning lebih tinggi dari pada peningkatan hasil belajar biologi siswa dengan model Inquiry Learning
\end{abstract}

Kata Kunci: problem based learning, inquiry learning, peningkatan hasil belajar

\begin{abstract}
This study aims to determine the improvement of student biology learning outcomes using the Problem Based Learning (PBL) model and Inquiry Learning model in Class X of Lubuklinggau 2 Public High School. This research is a quantitative descriptive research using quasi-experimental methods. The population in this study were all students of Class X Lubuklinggau 2 State Senior High School, amounting to 391 students, while the research samples were class X.7 amounting to 39 students as experimental class I and class X.10 totaling 40 students as experimental class II obtained using techniques cluster sampling. The research data was obtained by the test technique in the form of essay questions. Data analysis techniques with t test. The results of the study, based on the results of the analysis with the $t$ test on the final value, can be concluded that Ho is rejected and $\mathrm{Ha}$ is accepted because of the value of Sig. (2-tailed) of 0.513 greater than $\alpha=0.05$. Conclusion, the increase in biology learning outcomes of students with Problem Based Learning learning models is higher than the increase in student biology learning outcomes with the Inquiry Learning model
\end{abstract}

Keywords: problem based learning, inquiry learning, improving learning outcomes 


\section{PENDAHULUAN}

Perubahan dan perkembangan pendidikan merupakan hal yang memang seharusnya terjadi sejalan dengan perubahan budaya kehidupan. Perubahan yang dimaksud adalah perbaikan pendidikan pada semua tingkat untuk mengantisipasi kepentingan masa depan. Pendidikan yang dapat mendukung pembangunan di masa depan adalah pendidikan yang dapat mengembangkan potensi peserta didik. Sehingga peserta didik mampu menghadapi permasalahan kehidupan dan dapat menerapkan ilmu yang dipelajari di sekolah dalam kehidupan (Al-Tabany, 2014).

Implementasi dari perbaikan pendidikan yaitu dengan memperbaiki kurikulum yang dijadikan sebagai pedoman untuk seluruh kegiatan pendidikan disekolah. Kurikulum yang saat ini sedang diterapkan di seluruh sekolah di Indonesia adalah kurikulum 2013. Pada kurikulum 2013 siswa dituntut aktif dalam pembelajaran, mampu menyelesaikan permasalah, menemukan solusi dari permasalahan, dan menerapkannya dalam kehidupan. Namun setelah dilakukan observasi di SMA Negeri 2 Lubuklinggau diperoleh informasi bahwa dalam pembelajaran biologi dikelas X SMA Negeri 2 Lubuklinggau ditemukan kurangnya partisipasi dan keaktifan siswa dalam mengikuti pembelajaran biologi dan kurangnya penguasaan konsep oleh siswa yang berdampak pada hasil belajarnya, sehingga menyebabkan nilai siswa rendah. Data hasil belajar Ujian Tengah Semester (UTS) menunjukan dari 391 siswa yang mencapai ketuntasan hasil belajar sebanyak 124 dan yang belum mencapai ketuntasan hasil belajar 267 dengan persentase yang tuntas sebesar $32,24 \%$ dan persentase yang tidak tuntas sebesar $69,42 \%$.

Berdasarkan hasil observasi yang telah dilakukan, maka perlu diterapkan model pembelajaran yang melibatkan siswa secara aktif dalam pemecahan masalah dan menemukan solusi dari permasalahan tersebut sehingga mampu meningkatkan hasil belajarnya. Model pembelajaran yang dapat diterapkan adalah model Problem Based Learning (PBL)dan model Inquiry Learning. Ngalimun (2012) menyatakan model Problem Based Learning (PBL) adalah model pembelajaran yang melatih dan mengembangkan kemampuan siswa untuk menyelesaikan masalah dengan menggunakan metode ilmiah. Sedangkan menurut Hamdayama (2014) model Inquiry Learning merupakan suatu rangkaiaan kegiatan pembelajaran yang menekankan pada proses berpikir secara kritis untuk mencari dan menemukan sendiri jawaban dari suatu masalah yang dipertanyakan.

Model Problem Based Learning (PBL) dan Inquiry Learning adalah model pembelajaran yang berbasis pada masalah dan menekankan siswa untuk berpikir kritis dalam menemukan dan menyelesaikan permasalahan melalui proses pembelajaran. Namun, model Problem Based Learning (PBL) berbeda dengan model Inquiry Learning, Inquiry Learning lebih menekankan pada masalah akademik sedangkanProblem Based Learning (PBL) lebih menekankan pada tugas atau situasi yang benar-benar nyata sebagai masalah dengan menggunakan 
aturan-aturan yang sudah diketahui, yaitu memfokuskan pada masalah dalam kehidupan nyata.

Penelitian yang telah dilakukan oleh Arysandi (2018) menunjukkan hasil bahwa pembelajaran biologi lebih efektiv dengan menggunakan model pembelajaran inkuiri yang dapat dibuktikan dengan adanya pengaruh model pembelajaran inkuiri terhadap hasil belajar biologi siswa. Hasil penelitian Supiandi (2016) juga menyatakan bahwa model Problem Based Learning (PBL) secara signifikan mampu meningkatkan kemampuan memecahkan masalah dan hasil belajar kognitif biologi siswa. Oleh karena itu, berdasarkan penelitian yang relevan dan kriteria kedua model pembelajaran tersebut maka perlu dilakukan penelitian dengan rumusan masalah apakah peningkatan hasil belajar siswa dengan model Problem Based Learning (PBL) berbeda dengan peningkatan hasil belajar siswa dengan model Inquiry Learning? Penelitian ini bertujuan untuk mengetahui perbedaan peningkatan hasil belajar siswa antara model Problem Based Learning (PBL) dengan Inquiry Learning.

\section{METODE PENELITIAN}

Metode penelitian yang digunakan adalah kuasi eksperimen dengan desain penelitian yang digunakan pada penelitian ini adalah control group pretestposttest.Populasi dalam penelitian ini adalah seluruh siswa kelas X SMA Negeri 2 Lubuklinggau tahun pelajaran 2015/2016 yang terdiri atas sepuluh kelas, sampel adalah kelas X.7 sebagai eksperimen I dan kelas X.10 sebagai eksperimen II yang diambil secara acak (cluster sampling). Teknik pengumpulan data yang digunakan dalam penelitian ini adalah teknik tes. Tes yang digunakan berupa butir soal essay sebanyak tujuh soal yang sesuai dengan standar kompetensi, kompetensi dasar dan indikator. Tes dilakukan sebanyak dua kali pada kelas eksperimen I dan kelas eksperimen II yaitu berupa tes kemampuan awal (pre-test) dan tes kemampuan akhir (post-test). Setelah dilakukan pre-test dan post-test kemudian di hitung peningkatan hasil belajar nya dengan menggunakan rumus $\mathrm{N}$-gain. Data yang diperoleh dianalisis normalitas dan homogenitasnya kemudian dianalisis dengan uji-t pada taraf signifikan $\alpha=0,05$.

\section{HASIL PENELITIAN}

Pada penelitian ini, sebelum memulai proses pembelajaran, terlebih dahulu dilakukanpre-test. Pre-testdilakukan untuk mengetahui kemampuan awal siswa. Setelah dilakukan pre-test baru kemudian dilakukan pembelajaran dengan model Problem Based Learning ( $P B L)$ pada kelas eksperimen 1 dan model Inquiry Learning pada kelas eksperimen 2. Setelah pembelajaran selesai baru kemudian dilakukan pos-test untuk mengetahui kemampuan siswa setelah melakukan kegiatan pembelajaran.Data hasil penelitian dapat dilihat pada tabel 1 berikut. 
Tabel 1 Hasil pengujian menggunakan uji t

\begin{tabular}{cccccc}
\hline Keterangan & \multicolumn{5}{c}{ t-test for Equality of Means } \\
\hline Gabungan N-Gain & $\mathrm{t}$ & $\mathrm{df}$ & $\begin{array}{c}\text { Sig. }(2- \\
\text { tailed })\end{array}$ & $\begin{array}{c}\text { Mean } \\
\text { Difference }\end{array}$ & $\begin{array}{c}\text { Std. Error } \\
\text { Difference }\end{array}$ \\
\cline { 2 - 6 } & 2.869 & 68 & .513 & .13129 & .04576 \\
\hline
\end{tabular}

Berdasarkan tabel 1 hasiluji perbedaan rata-rata N-Gain kelas Problem Based Learning (PBL) dan kelas Inquiry Learning memiliki nilai Sig. (2-tailed) sebesar 0,513 itu berarti Ha diterima karena Sig. (2-tailed) lebih besar dari $\alpha=$ 0,05 . Dengan demikian terdapat perbedaan peningkatan hasil belajar biologi siswa antara kedua kelas. Dilihat dari perbedaan secara keseluruhan, dari rata-rata peningkatan hasil belajar kelas $\operatorname{PBL}(0,67)$ lebih tinggi dari kelas Inquiry Learning $(0,54)$. Untuk lebih jelasnya perbedaan peningkatan hasil belajar kedua kelas dapat dilihat pada gambar 1 .

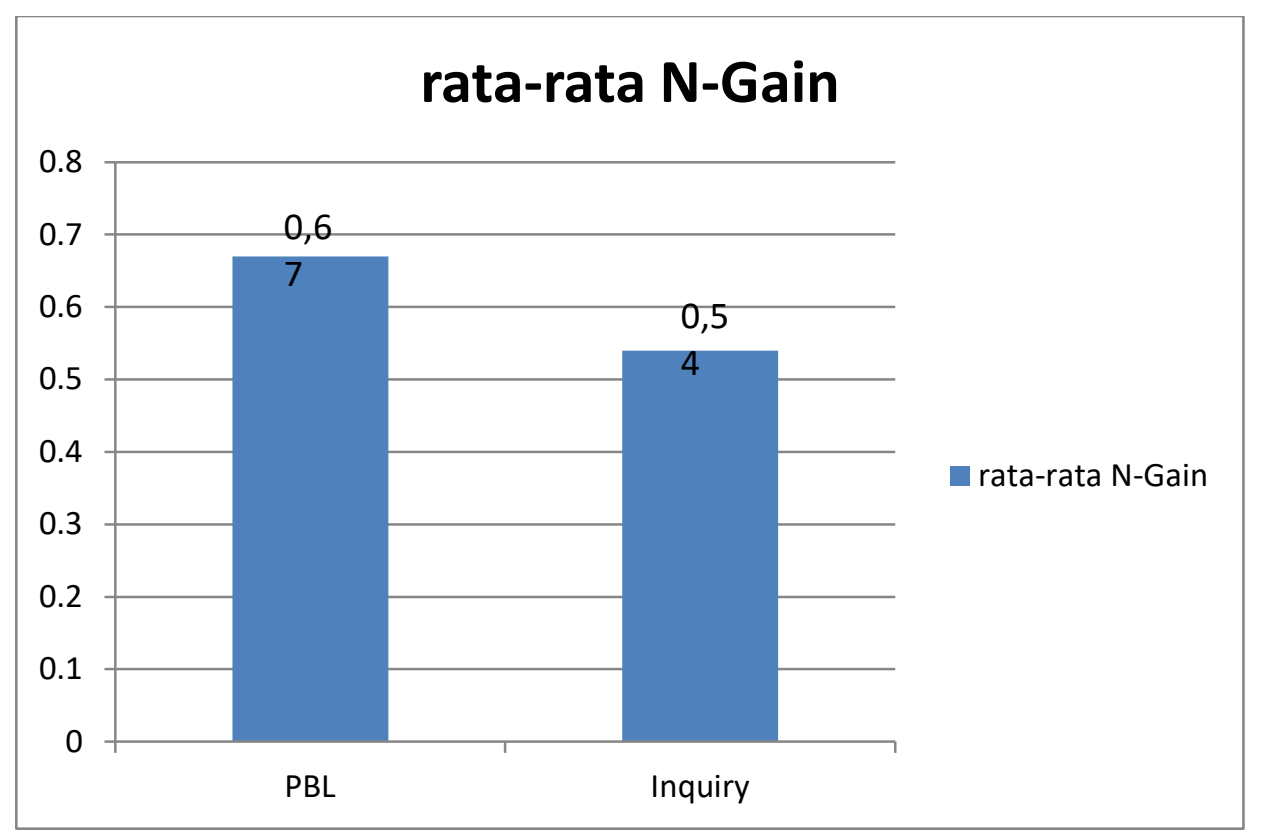

Gambar 1 perbedaan rata-rata peningkatan hasil belajar

\section{PEMBAHASAN}

Berdasarkan hasil pengamatan selama proses pembelajaran pada kelas eksperimen I dengan menggunakan model pembelajaran problem based learning siswa terlihat sangat serius dalam mengikuti pembelajaran, siswa lebih aktif dalam mencari informasi dari berbagai sumber, siswa lebih antusias dan lebih berani dalam mengemukakan pendapatnya lewat pertanyaan saat diskusi. selain itu pada saat pembelajaran menggunakan model problem based learning siswa terlihat berusahan bertanggung jawab, mandiri, dan dapat berkomunikasi untuk memecahkan masalah yang dibahas bersama anggota kelompoknya. Hal ini 
berdampak positif terhadap hasil belajar siswa. Hal ini didukung dengan pernyataan Sanjaya (2006), yang menyatakan bahwa model pembelajaran problem based learning suatu rangkaian aktivitas pembelajaran yang menekankan kepada proses pemecahan masalah, siswa tidak diharapkan hanya mendengar, mencatat, kemudian menghafal materi pembelajaran akan tetapi diarahkan untuk aktif berpikir, berkomunikasi, mencari dan mengelolah data. Penelitian yang dilakukan oleh Neliana (2016) juga menyatakan bahwa pada pembelajaran dengan menggunakan Problem Based Learning (PBL) aktivitas belajar siswa meningkat, hal ini terlihat pada saat mengajukan pertanyaan. Banyak siswa yang ingin mengajukan pertanyaan ketika diberi kesempatan bertanya. Aktivitas lain yang meningkat yaitu mengemukakan ide gagasan, mngumpulkan informasi, menyampaikan hasil diskusi, dan kemampuan dalam menyimpulkan jawaban dari permasalahan yang dikaji.

Sedangkan di kelas eksperimen II dengan menerapkan model pembelajaran inquiry, siswa terlihat kurang aktif dalam mencari jawaban dari suatu permasalahan dan kondisi kelas sukar dikendalikan sehingga keadaan kelas kurang kondusif karena siswa yang memiliki kemampuan kurang maksimal akan cendrung pasif dan kurang berpartisipasi dalam menemukan suatu jawaban dari permasalahan. Hal ini sesuai dengan pernyataan yang disampaikan oleh Ngalimun (2012), yang menyatakan bahwa model pembelajaran inquiry hanya mengembangkan disiplin dan kemampuan berpikir untuk mencari dan menemukan permasalahan secara mandiri dan Al-Tabany (2014), menyatakan salah satu kelemahan model pembelajaran inquiry yaitu mengalami kesulitan dalam mengontrol kegiatan dan keberhasilan siswa dalam proses pembelajaran.

Tingginya peningkatan hasil belajar siswa pada kelas eksperimen I dengan menggunakan model PBL disebabkan beberapa keunggulan dari penerapan model pembelajaran problem based learning yaitu seperti yang dikemukakan oleh Sanjaya (2006), pemecahan masalah dapat membantu siswa dalam mengembangkan pengetahuan barunya dan bertanggungjawab dalam pembelajaran yang mereka lakukan. selain itu masalah yang bersifat terbuka pada model pembelajaran problem based learning memberikan kesempatan pada siswa untuk bereksplorasi mengumpulkan dan menganalisis data secara lengkap untuk memecahkan masalah yang dihadapi sehingga siswa memiliki rasa tanggungjawab dalam menyelesaikan masalah dan didukung dengan pernyataan Ardana (2013), bahwa model pembelajaran problem based learning memungkinkan terciptanya pembelajaran yang kondusif bagi siswa, sehingga siswa belajar secara bermakna yang memungkinkan dapat menumbuh kembangkan keterampilan berpikir kritis siswa.

Selain itu perbedaan peningkatan hasil belajar siswa antara model PBL dengan model Inquiry Learning disebabkan karena karakteristik model PBL cenderung lebih mudah diterapkan kepada siswa karena prmasalahan yang ada berhubungan dengan kehidupan nyata siswa, permasalahan yang autentik, dan 
tidak didefinisikan secara ketat, memungkinkan kerja sama, dan bermakna bagi siswa. Sedangkan inquiry Learning permasalahan bersifat akademis dan berupa peristiwa atau situasi yang membingungkan, aneh dan kurang jelas sehingga siswa menjadi bertanya-tanya tentang hal itu dan yang memungkinkan untuk diselidiki secara cermat. Menurut Sanjaya (2006), masalah dalam pembelajaran problem based learning adalah masalah yang bersifat terbuka, jawaban dalam masalah tersebut belum pasti, setiap siswa bahkan guru dapat mengembangkan kemungkinan jawaban. Hal ini dapat memberikan kesempatan pada siswa bereksplorasi untuk mengumpulkan dan menganalisis data secara lengkap untuk memecahkan masalah yang dihadapi sedangkan masalah dalam pembelajaran inquiry adalah masalah yang bersifat tertutup, jawaban dari permasalahan itu sudah pasti, oleh sebab itu jawaban dari permasalahan yang dikaji sebenarnya guru sudah mengetahui dan memahaminya namun guru tidak langsung menyampaikannya kepada siswa.

Hasil penelitian ini juga didukung penelitian sebelumnya yang dilakukan oleh Soleh (2014), berdasarkan hasil penelitian yang dilakukan diketahui bahwa terdapat perbedaan keterampilan proses sains dengan penerapan model pembelajaran problem based learning dan inkuiri terbimbing pada siswa kelas X SMA Negeri 3 Boyolali tahun pelajaran 2013/2014 dengan nilai rata-rata pada pembelajaran yang menggunakan model pembelajaran problem based learning lebih tinggi dari pada model pembelajaran inkuiri terbimbing. Selain itu penelitian yang dilakukan oleh Nyonita (2014), menunjukan hasil bahwa ada perbedaan hasil belajar biologi pada penerapan model pembelajaran inquiry based learning dengan penerapan model pembelajaran problem based learning. Hasil belajar biologi pada penerapan model pembelajaran problem based learning lebih tinggi dari pada penerapan model pembelajaran inquiry based learning pada siswa kelas X SMA Negeri 5 Surakarta. Penelitian yang dilakukan oleh Handoyono (2016) juga menunjukkan hasil bahwa hasil belajar tertinggi diperoleh siswa yang proses pembelajarannya menggunakan metode Problem Based Learning (PBL) yang kemudian diikuti oleh metode inquiry learning dan yang terendah adalah metode konvensional. Pembelajaran dengan metode inquiry learning akan lebih baik diterapkan pada siswa yang memiliki motivasi tinggi, sedangkan metode Problem Based Learning (PBL) juga baik diterapkan pada siswa yang memiliki motivasi rendah

\section{SIMPULAN}

Berdasarkan hasil penelitian yang telah dilakukan, dapat disimpulkan bahwa terdapat perbedaan peningkatan hasil belajar biologi siswa antara kelas eksperimen I menggunakan model Problem Based Learning (PBL) dengan kelas eksperimen II menggunakan model Inquiry Learning. Peningkatan hasil belajar biologi siswa dengan model Problem Based Learning (PBL) lebih tinggi yaitu sebesar 0,67 dari pada model Inquiry Learning yaitu sebesar 0,54. 


\section{DAFTAR PUSTAKA}

Al-Tabany, T. I. B. (2014). Mendesain Model Pembelajaran Inovatif, Progresif, dan Kontekstual. Jakarta: Kencana.

Ardana. I K, (2013). Studi Komperatif Penerapan Model Pembelajaran Berbasis Masalah dan Model Pembelajaran Kooperatif Tipe STAD Terhadap Keterampilan Berpikir Kritis dan Kinerja Ilmiah Biologi SMA. e-journal Program Pascasarjana Universitas Pendidikan Ganesha Program Studi $I P A, 3(1)$. 12. [online]. http://pasca.undiksha.ac.id.

Arisandy, D. A., Fitriani, L., \& Ghassani, F. (2018). Efektivitas Model Pembelajaran Inquiry terhadap Hasil Pembelajaran Biologi Siswa Kelas X SMA Negeri 6 Lubuklinggau. BIOEDUSAINS: Jurnal Pendidikan Biologi Dan Sains, 1(1); 71-79. doi:10.31539/bioedusains.v1i1.267

Hamdayama, J. (2014). Model dan Metode Pembelajaran Kreatif dan berkarakter. Jakarta: Ghalia Indonesia.

Handoyono, NA. (2016). Pengaruh Inquiry Learning dan Problem Based Learning Terhadap Hasil Belajar PKKR Ditinjau dari Motivasi Belajar. Jurnal Pendidikan Vokasi, 6(1); 31-42.

Neliana, (2016). Pengaruh Model Problem Based Learning terhadap Aktivitas dan Hasil Belajar Siswa. Jurnal Bioterdidik: Wahana Ekspresi Ilmiah, 4(1).

Ngalimun. (2012). Strategi dan Model Pembelajaran. Yogyakarta: Aswaja Pressindo.

Nyonita. T, (2014). Study Komparasi Hasil Belajar Biologi dengan Penerapan Model Pembelajaran Inquiry Based Learning (IBL) dan Problem Based Learning (PBL) Pada Siswa Kelas X SMA Negeri 5 Surakarta Tahun Pelajaran 2013/2014. Bio-Pedagogi, 3(2). 29. [Online]. http://jurnal.fkip.uns.ac.id.

Sanjaya, W. (2006). Strategi Pembelajaran Berorientasi Standar Proses Pendidikan. Jakarta: Kencana.

Soleh. Y. M, (2014). Studi Komparasi Penerapan Model Pembelajaran Problem Based Learning dan Model Pembelajaran Ikuiri Terbimbing Terhadap Keterampilan proses Sains Siswa Kelas X SMA Negeri 3 Boyolali Tahun Pelajaran 2013/2014. Bio-Pedagogi, 3(2). 9. [online]. http://jurnal.fkip.uns.ac.id.

Supiandi, M.,I \& Julung, H. (2016). Pengaruh Model Problem Based Learning (PBL) terhadap Kemampuan Memecahkan Masalah dan Hasil Belajar Kognitif Siswa Biologi SMA. Jurnal Pendidikan Sains, 4(2);60-64. 